\title{
GAMBARAN HISTOPATOLOGIK HATI TIKUS WISTAR YANG DIBERIKAN AIR REBUSAN DAUN SENDOK (PLANTAGO MAJOR) PASCA INDUKSI KARBON TETRAKLORIDA $\left(\mathrm{CCl}_{4}\right)$
}

\author{
${ }^{1}$ Pinkan Lintong \\ ${ }^{2}$ Carla Kairupan \\ ${ }^{2}$ Poppy Lintong \\ ${ }^{1}$ Kandidat Skripsi Fakultas Kedokteran Universitas Sam Ratulangi Manado \\ ${ }^{2}$ Bagian Patologi Anatomi Fakultas Kedokteran Universitas Sam Ratulangi Manado \\ Email: pinkanjlintong@yahoo.com
}

\begin{abstract}
The common plantain (plantago major) contains the compound aucubin which has been demonstrated to have theraupetic effects in improving liver cells as hepatoprotector. The objective of this study was to reveal the histopathological features of the liver of wistar rats administered with the hot water extract of Plantago major after induction with carbon tetrachloride $\left(\mathrm{CCl}_{4}\right)$. This study was a laboratory experimental research employing 14 wistar rats; two rats were used as the negative control fed with regular pellets for 5 days, two rats as the positif control fed with pellets containing $\mathrm{CCl}_{4}$ of 0.05 cc for five days, five rats as treatment group receiving pellets containing $\mathrm{CCl}_{4}$ of $0.05 \mathrm{cc}$ for five days and were fed with regular pellets afterwards, and five rats received pellets containing $\mathrm{CCl}_{4}$ of 0.05 cc for five days and were administered with the hot water extract of Plantago major of 1.6 cc. Results showed that rats in the negative control exhibited normal macroscopic and microscopic features. In the positive control group, the microscopic features demonstrated liver cells with steatosis. Meanwhile, the rats administered with the water extract of Plantago major showed liver cells which had regenerated. It is concluded that the administration of the water extract of Plantago major can improve the liver cells by diffuse regeneration.
\end{abstract}

Keywords: plantago major, regeneration, steatosis , wistar rats

\begin{abstract}
Abstrak: Daun sendok (Plantago major) mengandung senyawa aucubin yang telah terbukti berkhasiat memperbaiki fungsi sel hati dan sebagai hepatoprotektor. Tujuan penelitian ini adalah untuk melihat gambaran histopatologik hati tikus wistar yang diberikan air rebusan daun sendok pasca induksi karbon tetraklorida $\left(\mathrm{CCl}_{4}\right)$. Penelitian ini merupakan penelitian eksperimental laboratorium dengan menggunakan 14 ekor tikus wistar, dua tikus digunakan sebagai kontrol negatif dengan pemberian pellet biasa selama 5 hari, dua tikus sebagai kontrol positif yang diberikan pellet yang mengandung $\mathrm{CCl}_{4}$ dosis 0,05 cc selama 5 hari, lima tikus sebagai kelompok perlakuan dengan pemberian $\mathrm{CCl}_{4}$ dosis 0,05 cc selama 5 hari dilanjutkan pellet biasa, dan lima tikus diberikan $\mathrm{CCl}_{4} 0,05$ cc selama 5 hari dilanjutkan pemberian air rebusan daun sendok dosis 1,6 cc. Hasil penelitian ini menunjukkan gambaran makroskopik dan mikroskopik normal pada kelompok kontrol negatif. Pada kelompok kontrol positif gambaran mikroskopiknya menunjukkan sel hati dengan steatosis. Kelompok tikus yang diberikan air rebusan daun sendok gambaran mikroskopiknya menunjukkan sel-sel hati yang mengalami regenerasi. Disimpulkan bahwa pemberian air rebusan daun sendok memperlihatkan regenerasi hati secara difus.
\end{abstract}

Kata kunci: daun sendok, regenerasi, steatosis, tikus wistar. 
Hati merupakan organ utama untuk metabolisme dan detoksifikasi obat sehingga hati berpotensi mengalami kerusakan akibat beragam bahan kimia terapeutik atau lingkungan. Cedera hati dapat segera timbul atau memerlukan waktu beberapa minggu hingga bulan dan dapat berupa perlemakan hati (steatosis) nekrosis sel hati yang nyata, kolestasis, atau disfungsi hati yang terjadi perlahan. ${ }^{1}$

Radikal bebas serta zat toksik yang berlebihan dalam tubuh berperan penting terhadap terjadinya kerusakan sel atau jaringan hati. Penelitian terhadap efek radikal bebas seringkali menggunakan karbon tetraklorida $\left(\mathrm{CCl}_{4}\right)$ untuk menginduksi terjadinya kerusakan (nekrosis) hati. ${ }^{2}$ Dalam dunia medis $\mathrm{CCl}_{4}$ digunakan pada pengobatan infeksi cacing tambang dan cacing pita. ${ }^{3}$

Hepatotoksik yang ditimbulkan oleh $\mathrm{CCl}_{4}$ disebabkan oleh senyawa hasil metabolisme yang bersifat radikal bebas yang masuk ke dalam tubuh secara inhalasi, ingesti atau kontak langsung dengan kulit. Senyawa radikal bebas tersebut adalah Triklorometil $\left(\mathrm{CCl}_{3}\right)$ dan Triklorometilperoksi $\left(\mathrm{CCl}_{3} \mathrm{O}_{2}\right)$. Triklorometil dapat berikatan kovalen dengan protein, lemak dan DNA yang dapat memicu kerusakan sel-sel hati. Triklorometilperoksi menyebabkan terjadinya peroksidasi lemak yang menimbulkan disfungsi membran sel dan membran organel sel serta membentuk senyawa reaktif aldehid yang dapat menyebabkan kerusakan sel-sel hati. ${ }^{4,5}$

Tanaman herbal berkhasiat dapat digunakan untuk mengobati penyakit pada hati. Daun sendok (Plantago major) merupakan tumbuhan liar yang memiliki khasiat obat. Secara umum daun sendok berkhasiat sebagai antiradang, hepatoprotektor, melancarkan kemih, peluruh dahak, menghentikan batuk, dan memperbaiki penglihatan dan menormalkan aktivitas hati yang berlebihan. ${ }^{6}$ Bagian tanaman yang digunakan adalah biji (Semen plantaginis) atau seluruh tumbuhan (Herba plantaginis). ${ }^{7}$ Daun sendok mengandung senyawa aucubin yang terbukti berkhasiat memperbaiki fungsi sel hati dan merupakan suatu glikosida iridoid yang berperan dalam biosintesa mRNA dan berfungsi sebagai hepatoregenerator. ${ }^{8}$

Penelitian ini dilakukan untuk mengetahui gambaran histopatologik hati tikus wistar yang diberi air rebusan daun sendok pasca induksi karbon tetraklorida $\left(\mathrm{CCl}_{4}\right)$. Hasil penelitian ini memberikan manfaat untuk mempelajari gambaran histopatologik hati tikus wistar yang diberikan air rebusan daun sendok pasca induksi karbon tetraklorida $\left(\mathrm{CCl}_{4}\right)$ dan dapat memberikan informasi tentang efek air rebusan daun sendok (plantago major) terhadap kerusakan hati tikus wistar yang diakibatkan oleh karbon tetraklorida $\left(\mathrm{CCl}_{4}\right)$.

\section{METODE PENELITIAN}

Penelitian ini merupakan penelitian eksperimental laboratorium dengan menggunakan hewan percobaan tikus wistar. Penelitian dilakukan di Laboratorium Patologi Anatomi Fakultas Kedokteran UNSRAT Manado dalam jangka waktu 3 bulan.

Hewan percobaan yang digunakan sebanyak 14 ekor, diberi makan pellet dan masing-masing tikus dimasukkan dalam kandang sendiri sesuai kelompok. Pemberian air rebusan daun sendok ditentukan berdasarkan konsumsi manusia dengan berat rata-rata $50 \mathrm{~kg}$ dalam sehari, yaitu 400 cc air rebusan yang diperoleh dari perebusan 35 gram daun sendok dengan 800 cc air sampai tersisa 400 cc. Tikus yang digunakan memiliki berat rata-rata 200 gr, maka dosis ditentukan dengan menggunakan rumus: 200/50000 x 400cc/ hari dan didapatkan 1,6cc/hari.

Kelompok 1 sebagai kontrol negatif terdiri dari 2 ekor tikus yang diberikan pellet biasa selama 5 hari kemudian diterminasi hari ke-6. Kelompok 2 sebagai kontrol positif terdiri dari 2 ekor tikus diberikan pellet yang mengandung $\mathrm{CCl}_{4}$ selama 5 hari kemudian diterminasi hari ke-6. Kelompok 3 terdiri dari 5 ekor tikus yang diberikan pellet yang mengandung $\mathrm{CCl}_{4}$ selama 5 hari; pemberian $\mathrm{CCl}_{4}$ dihentikan pada hari ke-6, dilanjutkan 
dengan pemberian pellet biasa hari ke-6 sampai hari ke-14. Terminasi dilakukan 2 kali, yaitu pada hari ke-11 (3 ekor tikus) dan hari ke-15 (2 ekor tikus). Kelompok 4 terdiri dari 5 ekor tikus yang diberikan pellet yang mengandung $\mathrm{CCl}_{4}$ selama 5 hari; pemberian $\mathrm{CCl}_{4}$ dihentikan pada hari ke-6, dilanjutkan dengan pemberian air rebusan daun sendok hari ke-6 sampai hari ke-14. Terminasi dilakukan 2 kali, yaitu pada hari ke-11 (3 ekor tikus) dan hari ke15 (2 ekor tikus).

Tikus dianastesi menggunakan eter dan diotopsi untuk mendapatkan organ hati. Untuk pemeriksaan mikroskopik jaringan hati dibuat sediaan histopatologik di Pusat Diagnostik Patologi Anatomi Manado dan selanjutnya dilakukan perbandingan gambaran histopatologik organ hati tikus wistar kontrol dan perlakuan.

\section{HASIL DAN PEMBAHASAN}

Gambaran mikroskopik jaringan hati tikus wistar kontrol negatif terlihat normal (Gambar 1), sedangkan hati tikus wistar kontrol positif (diberikan pellet yang mengandung $\mathrm{CCl}_{4}$ selama 5 hari menunjukkan adanya steatosis makrovesikuler dimana sel-sel hati membesar, memiliki vakuola-vakuola kosong dan jernih serta inti terdesak ke tepi (Gambar 2). Karbon tetraklorida $\left(\mathrm{CCl}_{4}\right)$ menyebabkan peroksidasi lemak dan merusak struktur serta fungsi retikulum endoplasmik, sehingga terjadi perlemakan (steatosis) oleh karena kerusakan transpor lemak oleh lipoprotein. ${ }^{3}$

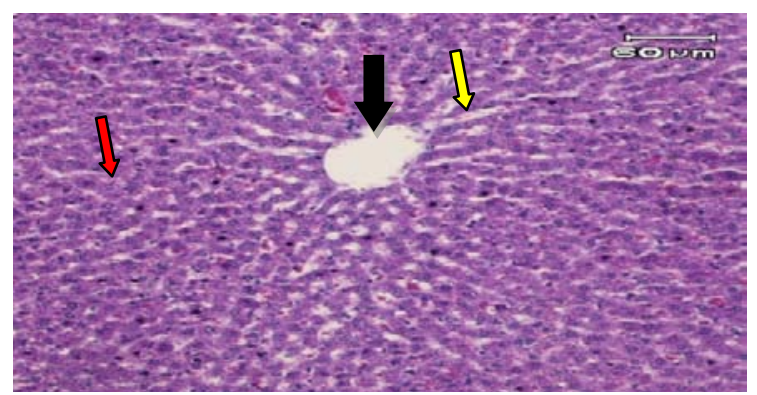

Gambar 1. Gambaran mikroskopik hati tikus wistar kontrol negatif. Ket: panah hitam: vena sentralis; panah kuning: sinusoid; panah merah: sel hati.

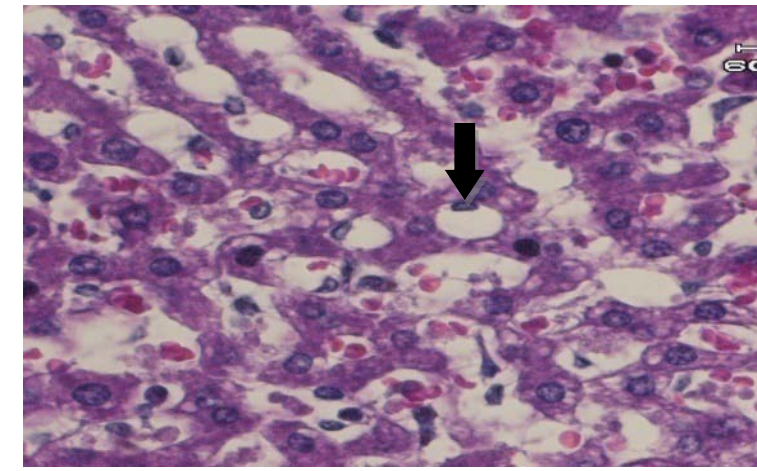

Gambar 2. Gambaran mikroskopik hati tikus wistar kontrol positif. Ket: panah hitam: steatosis makrovesikuler.

Pemberian $\mathrm{CCL}_{4}$ 0,05 cc/hari selama 5 hari dilanjutkan dengan pemberian pellet biasa, diterminasi hari ke-11 dibandingkan dengan yang diberikan $\mathrm{CCL}_{4}$ 0,05 cc/hari selama 5 hari dilanjutkan dengan pemberian air rebusan daun sendok 1,6 cc dan diterminasi hari ke-11. Secara mikroskopik masih terlihat sisa-sisa perlemakan dan ditemukan lebih banyak sel-sel regenerasi pada kelompok yang diberikan air rebusan daun sendok (Gambar 3) dibandingkan kelompok yang hanya diberikan pellet biasa (Gambar 4). Hal ini menunjukkan bahwa pemberian air rebusan daun sendok memicu proliferasi. Daun sendok mengandung senyawa aucubin yang terbukti berkhasiat memperbaiki fungsi sel hati dan merupakan suatu glikosida iridoid yang berperan dalam biosintesa mRNA dan berfungsi sebagai hepatoregenerator. ${ }^{7}$

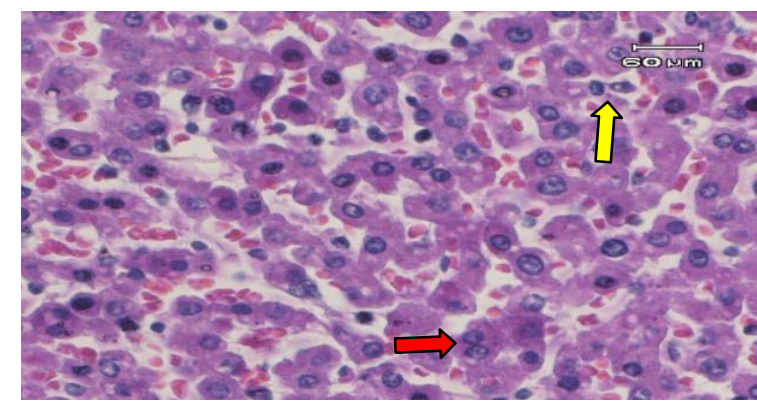

Gambar 3. Gambaran mikroskopik hati tikus wistar yang diberikan $\mathrm{CCl}_{4}$ dilanjutkan pemberian air rebusan daun sendok selama 5 hari. Ket: panah kuning: sisa perlemakan; panah merah: regenerasi sel 


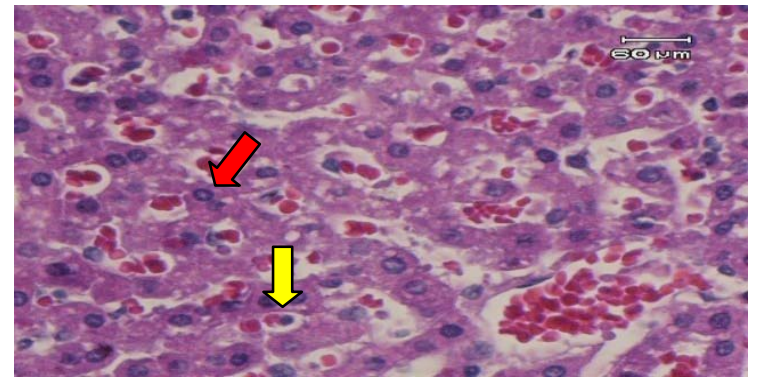

Gambar 4. Gambaran mikroskopik hati tikus wistar yang diberikan $\mathrm{CCl}_{4}$ dilanjutkan pemberian pellet biasa selama 5 hari. Ket: panah kuning: sisa perlemakan; panah merah: regenerasi sel.

Hasil yang lebih jelas terlihat pada kelompok tikus yang diberikan $\mathrm{CCL}_{4} 0,05$ $\mathrm{cc} /$ hari selama 5 hari dilanjutkan dengan pemberian pellet, diterminasi hari ke-15 dibandingkan dengan kelompok yang diberikan $\mathrm{CCL}_{4}$ 0,05 cc/hari selama 5 hari dilanjutkan dengan pemberian air rebusan daun sendok 1,6 cc dan diterminasi hari ke15. Secara mikroskopik kelompok dengan pemberian air rebusan daun sendok tampak memiliki banyak sel-sel yang mengalami regenerasi dengan lobulus-lobulus hati yang hampir menyerupai lobulus-lobulus hati normal seperti pada hati tikus kelompok kontrol negatif (Gambar 5), sedangkan pada kelompok dengan pemberian pellet biasa ditemukan sedikit regenerasi sel dan masih terdapat banyak sel-sel dengan steatosis (Gambar 6). Pada penelitian ini bentuk steatosis adalah steatosis makrovesikuler dan mikrovesikuler. Steatosis makrovesikuler menunjukkan gradasi beratnya cedera berupa perlemakan yang dapat disebabkan oleh $\mathrm{CCl}_{4}{ }^{3}$

Pada penelitian ini perbaikan jaringan hati yang cedera akibat $\mathrm{CCl}_{4}$ belum terlihat pada seluruh populasi sel, sebab masih terlihat sel hati dengan perlemakan terutama pada kelompok tikus yang tidak diberikan air rebusan daun sendok.

Jadi, kelompok tikus yang tidak diberikan air rebusan daun sendok membutuhkan waktu yang lebih lama untuk mengalami regenerasi sel hati. Dengan kata lain, penggunaan air rebusan daun sendok dapat membantu (mempercepat) regenerasi sel hati akibat cedera (perlemakan) oleh $\mathrm{CCl}_{4}$.

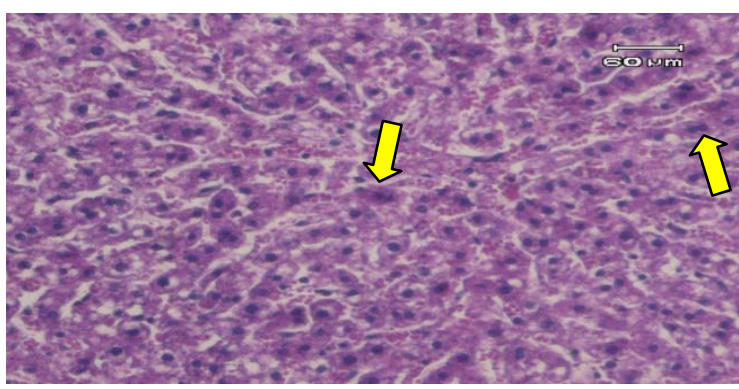

Gambar 5. Gambaran mikroskopik hati tikus wistar yang diberikan $\mathrm{CCl}_{4}$ dilanjutkan pemberian air rebusan daun sendok selama 9 hari. Ket: panah kuning: regenerasi sel.

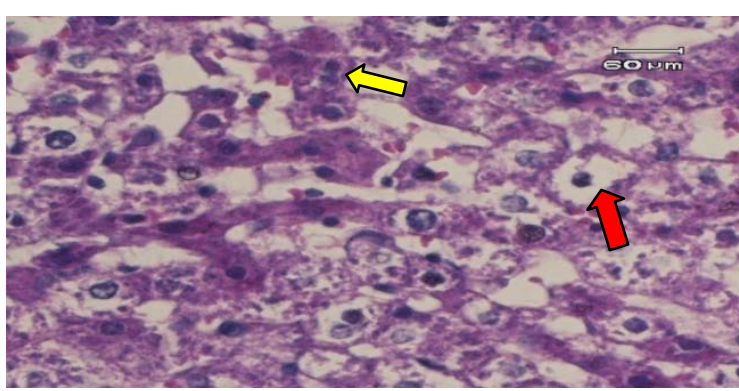

Gambar 6. Gambaran mikroskopik hati tikus wistar yang diberikan $\mathrm{CCl}_{4}$ dilanjutkan pemberian pellet biasa selama 9 hari. Ket: panah kuning: regenerasi sel; panah merah: steatosis makrovesikuler.

\section{SIMPULAN}

Pemberian $\mathrm{CCl}_{4}$ dosis 0,05 cC menyebabkan perlemakan sel hati (steatosis). Pemberian air rebusan daun sendok (plantago major) sebanyak 1,6 cc selama 9 hari memperlihatkan regenerasi sel secara difus.

\section{SARAN}

1. Untuk penelitian selanjutnya disarankan untuk menambahkan variasi dosis air rebusan daun sendok (plantago major) sehingga dapat diketahui dosis efektifnya.

2. Melakukan pemeriksaan kesehatan tikus wistar yang akan digunakan dalam penelitian. 


\section{DAFTAR PUSTAKA}

1. Kumar, Cotran, Robbins. Buku Ajar Patologi Robbins vol 2 (Edisi ke-7). Alih bahasa: Brahm U, Pendit. Jakarta: penerbit buku kedokteran EGC; 2007.

2. Wahyuni S. Pengaruh daun sambiloto (Andrographis paniculata, nees) terhadap kadar SGOT dan SGPT tikus putih. GAMMA. 2005;1(1):45-53.

3. Posangi J. Lesitin membantu regenerasi sel-sel hati tikus (wistar) yang cedera akibat $\mathrm{CCl}_{4}$. Journal of research and development. 2001;24(3):14,19,20.

4. Efek protektif teripang pasir (Holothuria scabra) terhadap hepatotoksisitas yang diinduksi karbon tetraklorida $\left(\mathrm{CCl}_{4}\right)$.
JURNAL IKD. 2009:3,4.

5. Junieva PN. Pengaruh pemberian ekstrak meniran (Phyllanthus sp.) terhadap gambaran mikroskopik paru tikus wistar yang diinduksi karbon tetraklorida [Skripsi]. Semarang: FK UNDIP; 2006.

6. Wijayakusuma HHM. Tumpas Hepatitis Dengan Ramuan Herbal. Jakarta: Pustaka Bunda; 2008.

7. Edijanti, Chodidja, Kusuma Rosy. Perbedaan kadar SGOT antara pemberian rebusan daun sendok dan daun sambiloto. Sains Medika. 2010;2(1):41-5.

8. Wijayakusuma, Hembing. Atasi Kanker Dengan Tanaman Obat. Jakarta: Puspa Swara; 2005. 